\title{
DEVELOPMENT OF NEW TECHNOLOGIES FOR CATTLE BREEDING SYSTEMS TAKING INTO ACCOUNT SUSTAINABLE ENVIRONMENTAL CONDITIONS
}

\author{
Jan Barwicki $^{\mathrm{a}^{*}}$, Maciej Kuboń ${ }^{\mathrm{b}}$, Andrzej Marczuk ${ }^{\mathrm{c}}$ \\ ${ }^{a}$ Institute of Technology and Life Sciences in Falenty, Warsaw Branch, Poland \\ ${ }^{\mathrm{b}}$ Institute of Agricultural Engineering and Informatics, University of Agriculture in Kraków, Poland \\ ${ }^{c}$ Department of Agricultural and Transport Machines, University of Life Sciences in Lublin, Poland \\ "Corresponding author: ul. Rakowiecka 32,02-532 Warsaw; email: j.barwicki@itp.edu.pl
}

\begin{tabular}{|c|c|}
\hline ARTICLE INFO & ABSTRACT \\
\hline $\begin{array}{l}\text { Article history: } \\
\text { Received: December } 2017 \\
\text { Received in the revised form: } \\
\text { March } 2018 \\
\text { Accepted: April } 2018\end{array}$ & \multirow{2}{*}{$\begin{array}{l}\text { Properly designed housing buildings, with regard to reduction of } \\
\text { a negative influence on environment, are necessary for ensuring } \\
\text { sustainable development in agriculture. The objective of this paper } \\
\text { was to show the results of environmental conditions research on high } \\
\text { milk yield dairy cattle in different housing systems. Temperature and } \\
\text { relative humidity of air and concentrations of harmful gases - ammo- } \\
\text { nia and carbon dioxide accompanying them were investigated. }\end{array}$} \\
\hline $\begin{array}{l}\text { Key words: } \\
\text { sustainable development, } \\
\text { cattle breeding systems, } \\
\text { harmful gases, } \\
\text { environment protection, } \\
\text { animal welfare, } \\
\text { energy balance }\end{array}$ & \\
\hline
\end{tabular}

\section{Introduction}

Rational development of technology in agriculture related to animal production approaches some very important parameters as: genetic progress, EU requirements for well being of animals living in a restricted area, existing limitations of environment protection and general expectations for the quality of the final product. It is proved that air exhausted from cattle barns contains some harmful components as: ammonia, methane, hydrogen sulphide, nitrous oxide, germs and dust (Bartali, Wheaton and Singh, 1999)

The research aimed at evaluation of the influence of different factors on sustainable development of agricultural technology on the example of cattle breeding systems and odor management in different aspects of technology development. Besides the impact of manure management on environment protection in rural areas, the area was indicated. 
Jan Barwicki, Maciej Kuboń, Andrzej Marczuk

\section{Material and methods}

The research covered analysis of three cattle barns with a different breeding technology located in family farms with a high - V level of mechanization. All barns had loose housing systems but different organization of manure removal. One barn had litter in cattle boxes, another one had no litter but rubber mats and the last one had deep litter pens (Fiedorowicz, Romaniuk, Wardal, 2011).

The analyses concerning environment protection were based on the following restrictions:

- carbon dioxide $\mathrm{CO}_{2} \leq$ gr $\mathrm{CO}_{2}(3000 \mathrm{ppm})$;

- ammonia $\mathrm{NH}_{3} \leq$ gr NH $\mathrm{NH}_{3}(20 \mathrm{ppm})$;

- hydrogen sulphide $\mathrm{H}_{2} \mathrm{~S} \leq \mathrm{gr} \mathrm{H}_{2} \mathrm{~S}$ (0,5 ppm) (Mazur, 2012).

Moreover, some tests concerning a relationship of the existing environment parameters and harmful gases concentration inside the barn according to the EU regulations were provided.

All mentioned barns are presented below in schemes in three separate figures.
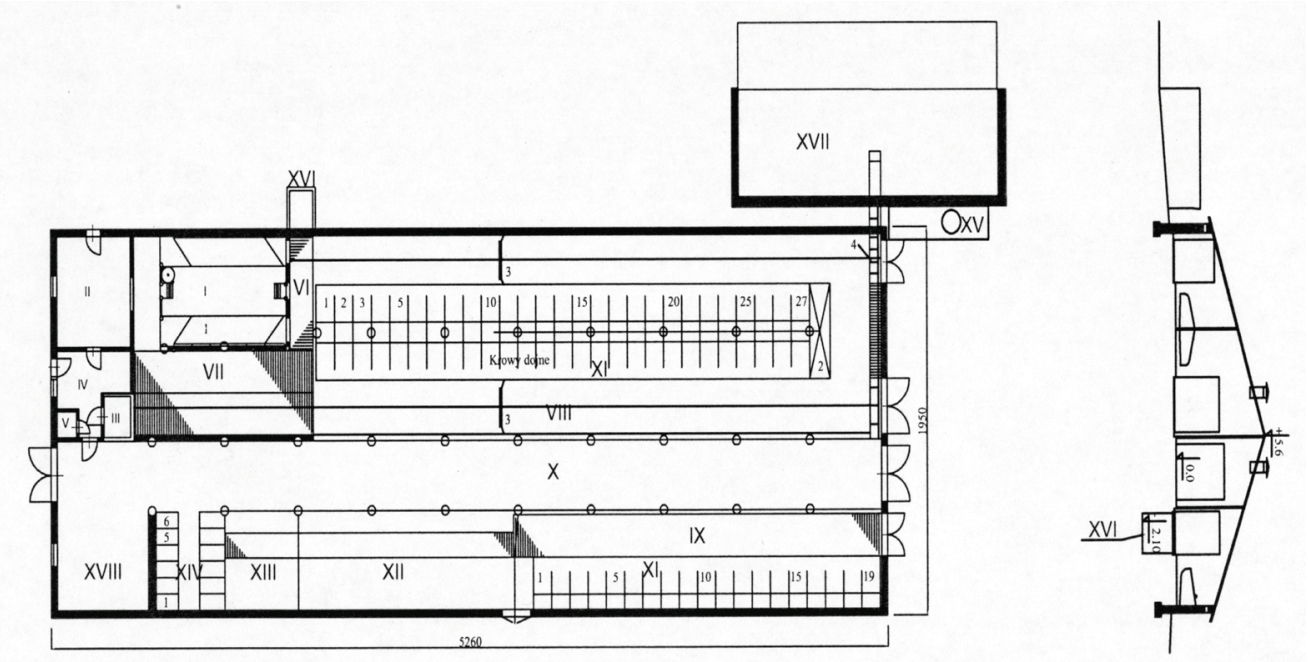

Figure 1. Scheme of loose housing barn with litter in boxes: I - milking parlour - „, herring bone" $2 \times 5$, II - milking room, III - power supply, IV sanitary room, $V$ - social room, $V I$ - waiting room before milking, VII - waiting room after milking, VIII-feeding area for milking cows, $I X$-feeding area for dry cows, $X X$-feeding corridor, XI-boxes for cows, $X V I$ - liquid manure tank, XVII - solid manure plate, 2 - double feeding station, 3,4 - manure scraper 
Development of new technologies...

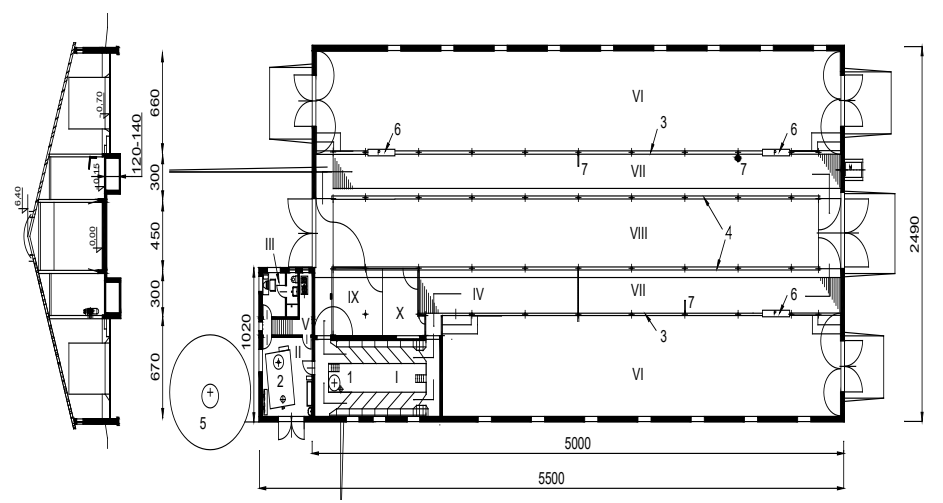

Source: Own elaboration

Figure 2. Scheme of loose housing barn with deep litter: I-milking parlor, II - milk storage room, III - office, IV - waiting room, $V$ - engine room, VI-pens with deep litter for cows, VII - feeding area on the slotted floor, VIII - feeding corridor, IX-delivery room, $X$-calf shed; 1 - herringbone milking parlor 2x6, 2 - milk cooling tank, 3 -wall, 4 -feeding barrier, 5 - silo for concentrate feeds, 6-drinking bowl, 7 -scratcher

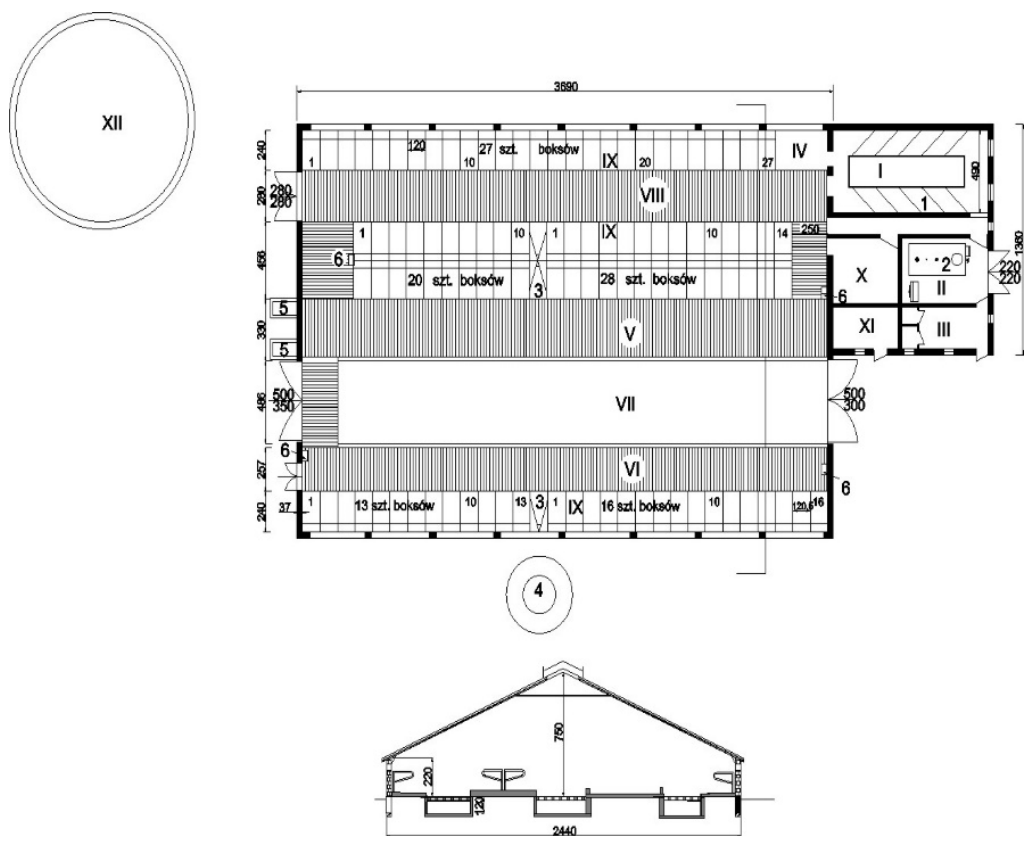

Source: Own elaboration

Figure 3. Scheme of loose housing barn with slotted floor and no litter in boxes: I-milking parlour , herring bone” $2 \times 5$, II - milking room , III-social room, VII-feeding corridor, $V$, VI, VIII-slotted floor, IX-boxes for milking cows, 3 -feeding station 
Jan Barwicki, Maciej Kuboń, Andrzej Marczuk

\section{Results}

The principal objective of this study was to determine the influence of the environment condition on animal welfare.

Intensive breeding of animals, as a response to the current increasing meat and milk consumption, causes that agriculture is one of the most troublesome sectors for the environment. It is related to the necessity of providing larger agricultural areas for cropping animal feeds, and with production of considerable amounts of slurry, creating thus a heavy environmental load.

In all the presented cattle barns, relative humidity of air exceeded the optimum. Average relative air humidity inside the tested cattle barns, ranged from 60.1 to $77.12 \%$, whereas the particular readings oscillated within 26.4-99.9\% (Romaniuk, Głaszczka, et al., 2012).

Relationship between $\mathrm{NH}_{3}$ concentration and relative humidity of air inside the cattle barn with rubber mats is presented in figure 4 .

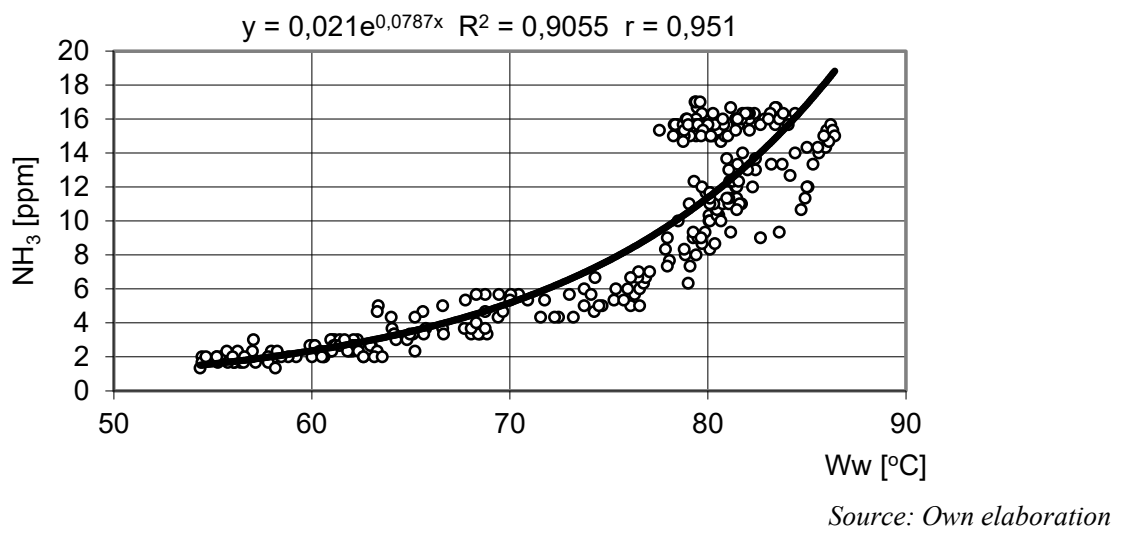

Figure 4. Relationship between $\mathrm{NH}_{3}$ concentration and relative humidity of air inside the cattle barn (boxes with litter). Number of freedom degrees $n-1=288$; confidence level $p=0.01$

The relationship between air temperature and relative humidity inside the cattle barn with litter is presented in figure 5 .

The average concentration of carbon dioxide in all cattle barns did not exceed 1000 p.p.m., which is recognized as comfortable conditions. Particular $\mathrm{CO}_{2}$ concentrations, varying from 280 to 2900 p.p.m., were within the standard accepted limits. The average ammonia concentration in the tested facilities was within the range from 3.39 to 8.72 p.p.m., which does not exceed the admissible limits (Romaniuk et al. 2012). 
Development of new technologies...

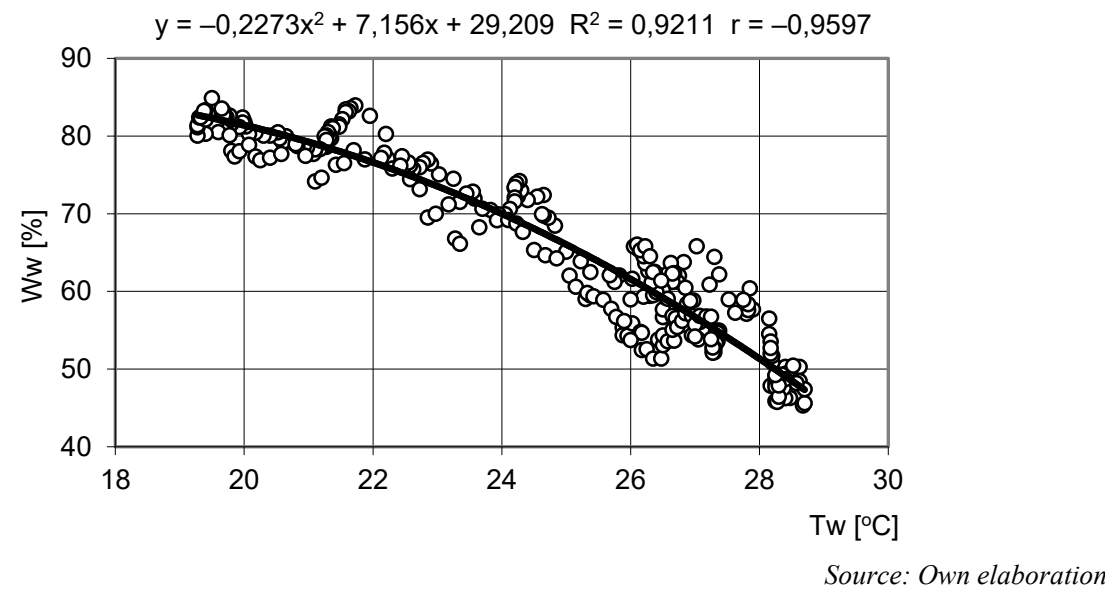

Figure 5. Relationship between air temperature and relative humidity inside the cattle barn (boxes with litter). Number of freedom degrees $n-1=288$; confidence level $p=0.01$

The relationship between $\mathrm{NH}_{3}$ concentration and air temperature inside the cattle barn with deep litter is presented in figure 6.

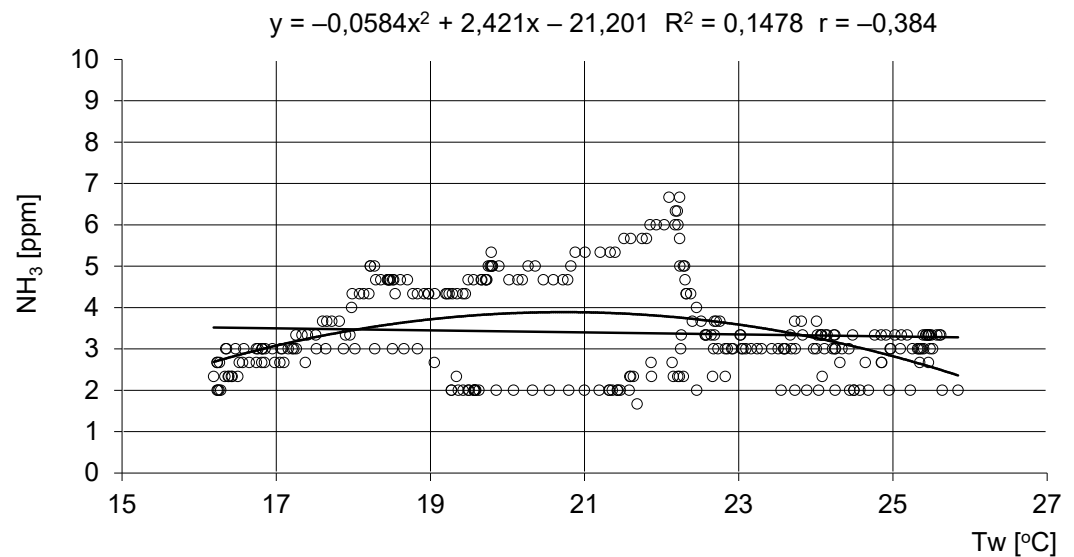

Source: Own elaboration

Figure 6. Relationship between $\mathrm{NH}_{3}$ concentration and temperature inside the cattle barn (deep litter) Number of freedom degrees $n-1=288$; confidence level $p=0.01$

The relationship between $\mathrm{NH}_{3}$ concentration and relative humidity inside the cattle barn with litterless boxes is presented in figure 7 .

Nitrogen in manure, similarly to ammonium, is a source of pollution of all elements of environment. 
Jan Barwicki, Maciej Kuboń, Andrzej Marczuk

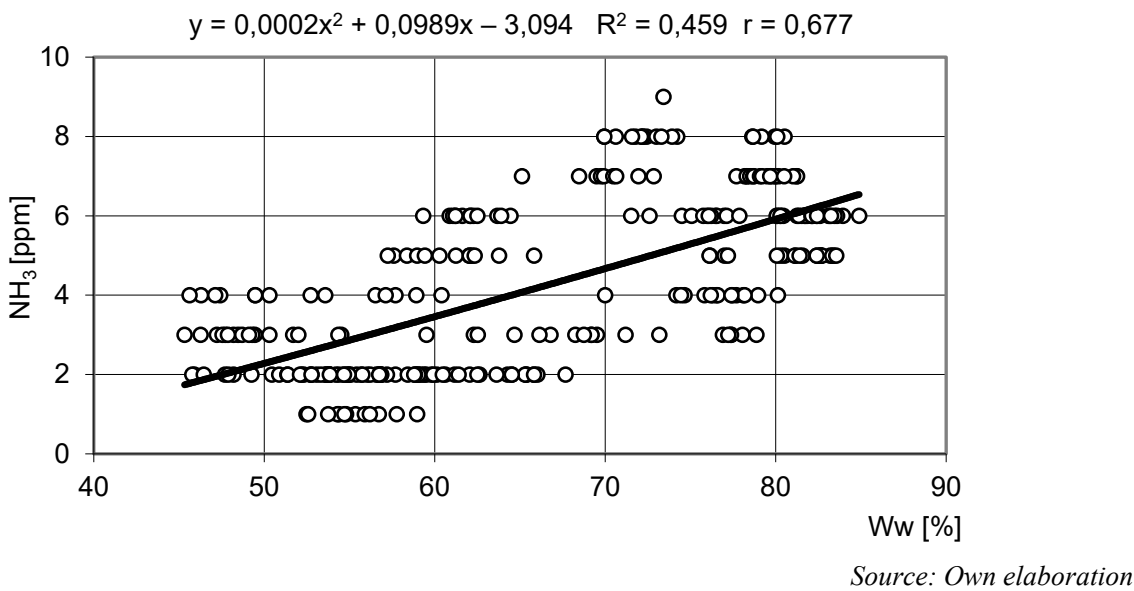

Figure 7. $\mathrm{NH}_{3}$ concentration depending on relative humidity of air inside the cattle barn (litterless boxes). Number of freedom degrees $n-1=288$; confidence level $p=0.01$

Manure utilization by means of generation and usage of energy from agriculture, gives some opportunities to diversify and increase the agricultural incomes and rural energetic security, as well as to improve the environment protection in rural areas (Wardal, 2012).

Table 1.

Measured environment parameters during provided research observations

\begin{tabular}{|c|c|c|c|c|c|c|c|c|c|c|}
\hline \multirow{4}{*}{$\begin{array}{l}\text { Cow } \\
\text { barn }\end{array}$} & \multirow{2}{*}{\multicolumn{2}{|c|}{$\begin{array}{c}\text { Temperature } \\
\left({ }^{\circ} \mathrm{C}\right)\end{array}$}} & \multirow{2}{*}{\multicolumn{2}{|c|}{$\begin{array}{l}\text { Relative humidity } \\
\text { (\%) }\end{array}$}} & \multicolumn{2}{|c|}{$\begin{array}{c}\text { Gas } \\
\text { concentration }\end{array}$} & \multirow{4}{*}{$\begin{array}{l}\text { Katharo- } \\
\text { metric } \\
\text { cooling } \\
\left(\mathrm{W} \cdot \mathrm{dm}^{-}\right. \\
2)\end{array}$} & \multirow{2}{*}{\multicolumn{2}{|c|}{$\begin{array}{l}\text { Air movement } \\
\text { velocity } \\
\left(\mathrm{m} \cdot \mathrm{s}^{-1}\right)\end{array}$}} & \multirow{4}{*}{$\begin{array}{l}\text { Lighting } \\
\text { (lx) }\end{array}$} \\
\hline & & & & & \multirow{2}{*}{\begin{tabular}{|c|}
$\begin{array}{c}\mathrm{CO}_{2} \\
(\mathrm{ppm})\end{array}$ \\
average
\end{tabular}} & \multirow{2}{*}{\begin{tabular}{|c|}
$\mathrm{NH}_{3}$ \\
$(\mathrm{ppm})$
\end{tabular}} & & & & \\
\hline & \begin{tabular}{|l|} 
average \\
outside \\
\end{tabular} & $\begin{array}{c}\text { average } \\
\text { inside }\end{array}$ & $\begin{array}{l}\text { average } \\
\text { outside }\end{array}$ & $\begin{array}{l}\text { average } \\
\text { inside }\end{array}$ & & & & $\begin{array}{c}\text { Katharo- } \\
\text { meter }\end{array}$ & $\begin{array}{c}\text { Thermo- } \\
\text { anemometer }\end{array}$ & \\
\hline & Range & Range & Range & Range & Range & Range & & average & average & \\
\hline \multirow[b]{2}{*}{1} & 5.10 & 11.50 & 72.00 & 60.30 & 932.60 & 4.50 & & & & \\
\hline & $1.7-10.8$ & 7.6-15.8 & $\begin{array}{l}41.0- \\
90.3\end{array}$ & $\begin{array}{c}36.0- \\
73.5\end{array}$ & $\begin{array}{l}500- \\
1900\end{array}$ & $1-9$ & 1.53 & 0.17 & 0.7242 & 140.00 \\
\hline \multirow[b]{2}{*}{2} & 18.26 & 21.02 & & 64.08 & 718.04 & 3.41 & & & & \\
\hline & $\begin{array}{l}11.4- \\
25.2\end{array}$ & $\begin{array}{l}15.7- \\
29.6\end{array}$ & b.d. & $\begin{array}{c}39.5- \\
80.5\end{array}$ & $\begin{array}{l}300- \\
1600\end{array}$ & $1-8$ & 2.39 & 0.16 & 0.6416 & 212.20 \\
\hline \multirow[b]{2}{*}{3} & 22.87 & 17.72 & 79.92 & 68.8 & 665.50 & 6.10 & & & & \\
\hline & $\begin{array}{l}16.7- \\
31.6\end{array}$ & $\begin{array}{l}11.9- \\
21.8\end{array}$ & $\begin{array}{l}40.8- \\
94.6\end{array}$ & $\begin{array}{c}46.0- \\
93.0\end{array}$ & $\begin{array}{l}300- \\
1500\end{array}$ & $1-19$ & 2.70 & 0.20 & 0.6832 & 124.25 \\
\hline
\end{tabular}

Source: Own elaboration 
Development of new technologies...

According to the Ministry of Agriculture, at considering the possibilities of using biomass of agricultural origin for energy purposes, long-term prospects and tasks for the agriculture should be taken into account. It has been assumed that until the year 2050, food production on the global scale can be doubled.

The above mentioned aim requires not only the increase of the unit production, but also supporting the accessible potential of agricultural production at proper culture, until it will be intended in total to food production. It is promoted by actual assignment of production surpluses for energy purposes, until the moment, when advanced technology enables to use the other renewable energy carriers.

In many cases, a farmer can and should not only supply the raw material, but also produce the electric and thermal energy, or be a supplier of biogas purified to the quality of natural gas, to the gas distribution network.

\section{Discussion and conclusions}

The average ammonia concentration in the investigated objects was within the range from 3.39 to 8.72 p.p.m., which does not exceed the admissible limits.

Also particular $\mathrm{CO}_{2}$ concentrations, varying from 280 to 2900 p.p.m., were within the standard accepted limits.

A loose housing system with slotted floor and no litter in boxes had promising results and obtained the following parameters:

- $\mathrm{CO}_{2}$ concentration in the range from $920 \mathrm{ppm}$ to $1850 \mathrm{ppm}$ and the average value of $1456 \mathrm{ppm}$,

- $\mathrm{NH}_{3}$ concentration in a range of $0.5-16.0 \mathrm{ppm}$ and the average of $10.5 \mathrm{ppm}$.

Generation and usage of energy from agriculture, give some opportunities to diversify and increase the agricultural incomes and rural energetic security, as well as to improve the environment protection of agriculture land.

That is a chance to improve the environment in rural areas by development of new energy sources and biogas production could be one of them (Fiedorowicz, et. al., 2011).

Provided experiments have proved that it is possible to obtain the following results:

- Reduction of greenhouse gases by about 20 percent

- Improvement of effectiveness of energy utilization by about 20 percent (lower usage of original energy),

- Increase of usage of renewable energy sources in the total energetic energy balance on the country scale by about 20 percent

\section{References}

CIGR Handbook of Agricultural Engineering. (1999). Volume II: Animal Production and Aquaculture Engineering. Part I Livestock Housing and Environment. Volume Editors: Bartali, E.H., Wheaton, F.W., Singh, S. pp. 395.

Fiedorowicz, G., Romaniuk, W., Wardal, W.J. (2011). Method of economic and technological assessment of solutions of the functional state, removal and storage of manure from barns. Problems of Agricultural Engineering, 4, 105-116. 
Jan Barwicki, Maciej Kuboń, Andrzej Marczuk

Mazur, K. (2012). Emission of harmful gases from cowsheds for dairy cows. Monography, Problems of intensification of animal production including environmental protection and alternative energy production, IPT, 100-105.

Romaniuk, W., Głaszczka, A., Biskupska, K. (2012). Analysis of biogas installations for family farms. Engineering in Agriculture. Monograph. ITP Falenty, 94.

Romaniuk, W., Mazur, K., Domasiewicz, T., Wardal, W.J., Biskupska, K. (2012). Formation of the environmental conditions in raising of dairy cattle existing status and reconstruction proposals, IPT, 100.

Wardal, W.J. (2012). Impact of cattle breeding system on manure removal and storage. PhD dissertation. Institute of Technology and Life Sciences. Falenty, 131.

\section{ROZWÓJ NOWYCH TECHNOLOGII W HODOWLI BYDLA BIORĄC POD UWAGE ZRÓWNOWAŻONE WARUNKI ŚRODOWISKOWE}

Streszczenie. Odpowiednio zaprojektowane budynki inwentarskie pod kątem ograniczenia negatywnego wpływu na środowisko są niezbędne dla zapewnienia zrównoważonego rozwoju w rolnictwie. Celem pracy było przedstawienie wyników badań warunków środowiskowych panujących w różnych systemach chowu bydła mlecznego o wysokiej wydajności mlecznej. Badano temperaturę i wilgotność względną powietrza oraz towarzyszące im stężenia szkodliwych gazów amoniaku i dwutlenku węgla.

Słowa kluczowe: zrównoważony rozwój, systemy hodowli bydła, szkodliwe gazy, ochrona środowiska, dobrostan zwierząt, bilans energetyczny 